\author{
Edubiotik : Jurnal Pendidikan, Biologi dan Terapan \\ ISSN 2528-679X (print), ISSN 2597-9833 (online) \\ Volume 5, Nomor 01, Tahun 2020, Hal. 42 - 54 \\ Available online at: \\ http://ejurnal.budiutomomalang.ac.id/index.php/edubiotik
}

Research Article

\title{
Perbedaan kemampuan berpikir kritis dan hasil belajar kognitif dengan model pembelajaran problem based learning berbantuan media audio visual
}

\author{
Meti Herlina, Jayanti Syahfitri, Ilista \\ Program Studi Biologi, Universitas Muhammadiyah Bengkulu, Bengkulu, Indonesia \\ Email: metyalina@umb.ac.id*, jayanti_syahfitri@yahoo.co.id, ilista28@gmail.com
}

\begin{tabular}{|c|c|}
\hline Informasi Artikel & ABSTRACT \\
\hline $\begin{array}{l}\text { Submit: } 14-01-2019 \\
\text { Diterima: } 25-02-2020 \\
\text { Dipublikasikan: } 27-02-2020\end{array}$ & $\begin{array}{l}\text { Utilization of problem based learning models assisted by learning media to improve } \\
\text { critical thinking skills and cognitive learning outcomes of students have not run } \\
\text { optimally. This study aims to determine the differences in critical thinking skills and } \\
\text { cognitive learning outcomes of students with problem based learning (pbl) learning } \\
\text { models assisted by audio-visual media in SMA Negeri } 06 \text { Bengkulu City. The research } \\
\text { method used was quasi-experimental with a randomized pretest-posttest control group } \\
\text { design. The study population was a class XI student of SMAN } 06 \text { Bengkulu City with } \\
\text { two groups namely experimental and control samples with each } 36 \text { people. The } \\
\text { instrument used, namely essay question test totaling } 5 \text { questions that measure critical } \\
\text { thinking and multiple-choice questions totaling } 10 \text { questions to measure cognitive } \\
\text { learning outcomes. The research data analysis technique used a t-test. The results } \\
\text { showed that there were differences in critical thinking skills and student cognitive } \\
\text { learning outcomes. This is evident from the } t \text {-count value of critical thinking skills of } \\
6.414 \text { (> t-table) and cognitive learning outcomes of } 5.826 \text { (> t-table). This research } \\
\text { concludes that there are differences in critical thinking skills and cognitive learning } \\
\text { outcomes of students with PBL models assisted by audio-visual media. } \\
\text { Key words: Cognitive, Critical thinking, Media, Pbl }\end{array}$ \\
\hline Penerbit & ABSTRAK \\
\hline $\begin{array}{l}\text { Program Studi Pendidikan Biologi, } \\
\text { IKIP Budi Utomo, Malang, Indonesia }\end{array}$ & $\begin{array}{l}\text { Pemanfaatan model pembelajaran problem based learning berbantuan media } \\
\text { pembelajaran untuk meningkatkan keterampilan berpikir kritis dan hasil belajar kognitif } \\
\text { siswa belum berjalan secara optimal. Penelitian ini bertujuan untuk mengetahui } \\
\text { perbedaan kemampuan berpikir kritis dan hasil belajar kognitif siswa dengan model } \\
\text { pembelajaran problem based learning (pbl) berbantuan media audio visual di SMA } \\
\text { Negeri } 06 \text { Kota Bengkulu. Metode penelitian yang digunakan adalah eksperimen } \\
\text { semu (quasi experiment) dengan desain randomized pretest posttest control group } \\
\text { design. Populasi penelitian adalah siswa kelas XI SMA Negeri } 06 \text { Kota Bengkulu } \\
\text { dengan dua kelompok sampel yaitu eksperimen dan kontrol dengan masing-masing } \\
\text { berjumlah } 36 \text { orang. Instrumen yang digunakan, yaitu tes berbentuk soal esai } \\
\text { berjumlah } 5 \text { soal yang mengukur berpikir kritis dan soal pilihan ganda berjumlah } 10 \\
\text { soal untuk menaukur hasil belaiar koanitif Teknik analisis data penelitian }\end{array}$ \\
\hline 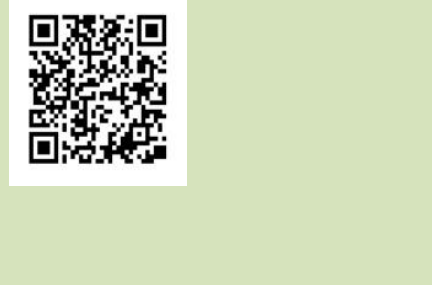 & $\begin{array}{l}\text { menggunakan uji-t. Hasil penelitian menunjukkan bahwa ada perbedaan kemampuan } \\
\text { berpikir kritis dan hasil belajar kognitif siswa. Hal ini terbukti dari nilai t-hitung } \\
\text { keterampilan berpikir kritis sebesar } 6,414 \text { (> t-tabel) dan hasil belajar kognitif sebesar } \\
5,826 \text { ( }>\text { t-tabel). Simpulan penelitian ini adalah ada perbedaan kemampuan berpikir } \\
\text { kritis dan hasil belajar kognitif siswa dengan model PBL berbantuan media audio } \\
\text { visual. } \\
\text { Kata kunci: Berpikir kritis, Kognitif, Media, Pbl }\end{array}$ \\
\hline
\end{tabular}

This Edubiotik : Jurnal Pendidikan, Biologi dan Terapan is licensed under a CC BY-SA (Creative Commons AttributionShareAlike 4.0 International License) 


\section{PENDAHULUAN}

Pendidikan menjadi faktor penting dalam pembangunan bangsa, karena melalui pendidikan kualitas sumber daya manusia dapat ditingkatkan dan dikembangkan dengan kata lain pendidikan merupakan sarana pengembangan potensi sumber daya manusia, (Syahfitri dkk, 2018). Pendidikan memiliki peran penting dalam menciptakan sumber daya manusia yang lebih produktif mengikuti perkembangan ilmu pengetahuan (Triyuningsih, 2011). Berkembangnya potensi siswa tidak terlepas dari proses pembelajaran. Kegiatan belajar yang efektif memungkinkan terjadinya pengembangan keterampilan sains dan kemampuan berpikir siswa (Pratiwi, 2012). Menurut Trianto (2015), hakikat IPA adalah ilmu pengetahuan yang mempelajari gejala-gejala melalui serangkaian kegiatan yang dikenal dengan proses ilmiah yang terdiri atas beberapa komponen. Perlu dikembangkan suatu model pembelajaran IPA yang melibatkan siswa secara aktif dalam kegiatan pembelajaran untuk menemukan atau menerapkan sendiri ide-idenya.

Sucipto (2017) menjelaskan bahwa berpikir merupakan aktivitas mental yang terjadi apabila seseorang menghadapi masalah atau situasi yang harus dipecahkan. Berpikir yang dimaksud yaitu berpikir tingakt rendah (lower thinking) dan berpikir tingkat tinggi (higher thinking). Ciri-ciri seseorang memiliki keterampilan berpikir tingkat tinggi adalah mampu berpikir kritis dan berpikir kreatif (Jamilatus et al., 2018). Berpikir kritis merupakan suatu kegiatan berpikir secara terorganisir dalam memecahkan masalah. Berpikir kritis dalam memecahkan masalah tidak terlepas dari aktivitas mental yang melibatakan kemampuan, yaitu memberikan penjelasan, merumuskan suatu masalah, memberikan pendapat, mengambil kesimpulan baik secara deduksi dan induksi, serta melakukan evaluasi dan mengambil keputusan (Reta, 2012). Syahfitri dkk (2019a) mengungkapkan bahwa tuntutan kurikulum dalam pembelajaran membutuhkan siswa yang dapat terlibat aktif dalam berpikir kritis sebagai bentuk persiapan menghadapi abad ke 21. Hal ini juga dipertegas oleh pernyataan Syahfitri (2019b); Kirmizi et al., (2015) yang mengungkapkan bahwa berpikir kritis merupakan tujuan utama dalam pengembangan pendidikan dan dianggap sebagai salah satu cara untuk menghadapi tantangan global.

Dalam rangka menghadapi abad ke-21 menuntut seseorang untuk memiliki berbagai keterampilan, sehingga diharapkan pendidikan dapat mempersiapkan siswa untuk menguasai berbagai keterampilan tersebut agar menjadi pribadi yang sukses dalam hidup (Zubaidah, 2016). Proses penguasaan keterampilan abad 21 tidak terlepas dari adanya peran guru yang mampu memberikan keteladanan dan mampu menciptakan minat, serta mengembangkan potensi dan kreativitas peserta didik (Winarti, 2015). Berdasarkan hasil observasi awal dengan pengamatan di SMA Negeri 6 Kota Bengkulu pada tanggal 19 Desember 2017, diperoleh informasi dari salah satu guru Biologi bahwa di SMA Negeri 06 Kota Bengkulu telah menerapkan Kurikulum 2013 (K13) dan dalam proses pembelajaran guru sudah menggunakan model pembelajaran yaitu student teams achievement division (stad) dan juga menggunakan media pembelajaran seperti power point. Walaupun guru sudah menggunakan model dan media pembelajaran tetap saja masih ada siswa yang belum tuntas KKM. Berdasarkan nilai hasil ujian semester ganjil pada mata pelajaran Biologi tahun akademik 2017/2018, dimana KKM untuk kelas XI MIPA yaitu 75 yang setiap kelasnya rata-rata terdiri dari 36 siswa yang tuntas KKM hanya $62 \%$ dengan nilai rata-rata 61,44 . Selanjutnya hasil belajar siswa pada mata pelajaran biologi khususnya pada kelas XI MIPA, pembelajaran dianggap tuntas apabila siswa mencapai nilai rata-rata 75 sebanyak $85 \%$. Fakta ini menunjukkan bahwa proses pembelajaran yang diterapkan kepada siswa perlu dibenahi lagi agar hasil belajar pada aspek kognitif siswa lebih baik dari yang sebelumnya. 
Fakta lain yang ditemukan adalah siswa masih kurang diberdayakan dalam mengolah keterampilan berpikir kritis. Siswa masih cenderung pasif dalam kegiatan pembelajaran. Siswa hanya sekedar menerima informasi yang disampaikan oleh guru. Hal ini disebabkan karena model pembelajaran yang digunakan belum menarik, kegiatan belajar cenderung tidak memotivasi berpikir kritis. Pada aspek tingkat tinggi seperti menemukan masalah belum biasa dilatihkan kepada siswa. Hal ini dilihat dari siswa masih mengalami kesulitan dalam mengaplikasikan pengetahuan yang dimiliki untuk memecahkan permasalahan dalam kehidupan sehari-hari. Sebagian siswa juga merasa belum terbiasa terlibat aktif dalam menyelesaikan suatu permasalahan yang didahului dengan kegiatan penyelidikan. Melihat fakta ini diharapkan bahwa jika prinsip penyelesaian masalah telah digunakan dalam pembelajaran, maka memungkinkan siswa untuk dapat membiasakan diri untuk terlibat secara aktif dalam berpikir kritis (Reta, 2012).

Keterampilan berpikir kritis memungkinkan peserta didik untuk mengambil keputusan dari berbagai sudut pandang secara cermat, teliti, dan logis. Dengan kata lain dengan keterampilan berpikir kritis peserta didik akan mampu berpikiran terbuka, serta mampu mengungkapkan pendapatnya sendiri (Sari, 2012). Hal ini menegaskan bahwa proses pembelajaran di sekolah diharapkan mampu menciptakan kegiatan yang melatih siswa dalam menggali kemampuan untuk mencari, mengolah, dan menilai berbagai informasi secara kritis. Nasution dan Sirait (2016) menjelaskan bahwa proses pembelajaran dengan cara memberi pengalaman secara langsung akan mengembangkan kemampuan berpikir siswa, dimana siswa diarahkan untuk mencari tahu dan pengetahuan yang tinggi dalam memecahkan suatu fenomena alam.

Permasalahan yang ditemukan dapat diatasi dengan penggunaan suatu model pembelajaran yang bervariasi dengan media pembelajaran untuk meningkatkan kemampuan berpikir kritis siswa. Hasan dan Syatriandi (2018) mengungkapkan bahwa kemampuan berpikir kritis sangat penting dikembangkan dalam proses pembelajaran, karena siswa dituntut untuk mengeluarkan pendapat mereka masing-masing tentang masalah yang diberikan oleh guru dalam proses pembelajaran. Untuk menciptakan suasana pembelajaran yang kondusif dan menyenangkan perlu adanya pengemasan model pembelajaran yang menarik sehingga peserta didik tidak merasa terbebani oleh materi ajar yang harus dikuasai. Nafiah (2014) menyebutkan bahwa model pembelajaran yang dapat meningkatkan cara berpikir kritis dan hasil belajar kognitif siswa yaitu dengan menggunakan model pembelajaran problem based learning (pbl).

Menurut Kinaseh, dkk (2015) pembelajaran berbasis masalah merupakan suatu proses pembelajaran yang bercirikan adanya serangkaian kegiatan pemecahan masalah, sehingga selain siswa dapat mempelajari konsep-konsep yang berhubungan dengan masalah tetapi siswa juga memahami metode ilmiah yang digunakan dalam memecahkan masalah tersebut. Hasmiati dkk, (2018) mengungkapkan bahwa model pbl sangat cocok untuk mengembangkan kemampuan berpikir kritis dan hasil belajar kognitif siswa dalam memecahkan masalah, karena melalui model pbl siswa siswa dapat megembangkan penegtahuan yang dimiliki dalam mengatasi masalah dan membuat berbagai macam solusi yang akan meningkatkan kemampuan berpikir dan hasil belajar.

Menurut Novitasari, dkk (2015) menyatakan bahwa pbl mampu meningkatkan hasil belajar berupa kemampuan berpikir kritis dengan kategori baik, keterampilan dengan kategori sangat baik, dan sikap dengan kategori baik. Selain itu pbl mampu memotivasi siswa untuk belajar. Penerapan model pembelajaran sangat membutuhkan sebuah media pembelajaran. Salah satu media yang dapat digunakan adalah media visual berupa video. Prastowo (2019) mengungkapkan bahwa video termasuk dalam kategori bahan ajar audio visual. Dengan kombinasi dua materi ini (materi visual dan auditif), 
pendidik dapat menciptakan proses pembelajaran yang lebih berkualitas, karena komunikasi berlangsung secara efektif.

Syaribuddin, dkk (2016) mengungkapakn bahwa penggunaan media pembelajaran berkaitan dengan tahapan berpikir. Media pembelajaran dapat menjadikan hal-hal yang bersifat abstrak dapat direfresentasikan secara lebih konkret. Selain itu media pembelajaran inovatif berbasis teknologi informasi dan komunikasi (audio visual) sangat membantu guru dalam proses pembelajaran, karena dapat menjadikaan siswa merasa senang, tertarik, dan mudah dalam memahami materi (Suharjanto dkk, 2013). Paramartha, dkk (2016) menyatakan media audio visual merupakan media visual yang menggabungkan penggunaan suara yang memerlukan pekerjaan tambahan untuk memproduksinya.

Model pembelajaran problem based learning berbantuan media audio visual merupakan model pembelajaran yang menitikberatkan pada penggunaan masalah di dunia nyata yang melibatkan siswa untuk memecahkan masalah tersebut (student center). Penggunaan media audio visual membuat siswa mudah memahami suatu konsep dengan utuh. Apabila siswa sudah bisa memahami suatu konsep pembelajaran (pembelajaran dengan student center), maka bisa dinyatakan hasil belajar kognitif siswa juga akan meningkat dan begitu sebaliknya. Hal ini sejalan dengan ungkapan Paramartha, dkk (2016) menyatakan media audio visual sebagai pendukung penerapan model problem based learning dalam pembelajaran memiliki beberapa karakteristik dan keunggulan. Hal ini didukung dengan pernyataan Fradisa dan Kartika (2019) bahwa pembelajaran yang berlangsung student center atau teacher center secara tidak langsung akan mempengaruhi tinggi rendahnya hasil belajar siswa. Tujuan penelitian ini adalah untuk mengetahui perbedaan kemampuan berpikir kritis dan hasil belajar kognitif siswa model pembelajaran problem based learning menggunakan media audio visual.

\section{METODE PENELITIAN}

Penelitian ini merupakan jenis penelitian eksperimen semu (quasi eksperiment). Desain penelitian yang digunakan yaitu randomized pretest posttest control group design. Rancangan dalam penelitian ini dimulai dengan pemberian pretest kepada siswa di kedua kelas ekperimen dan control yang bertujuan untuk mengetahui kemampuan awal siswa sehingga bisa digunakan sebagai pedoman penempatan siswa dalam kelompok. Siswa kelas eksperimen diberi perlakuan dengan menggunakan model pembelajaran problem based learning (pbl) menggunakan audio visual, sedangkan kelas kontrol diberi pembelajaran konvensional. Setiap siswa pada kelas eksperimen dan kontrol diberikan postes. Hasil belajar siswa yang diperoleh akan dihitung rata-ratanya menggunakan uji-t. Adapun tahapan dalam penelitian ini yaitu: 1. Tahap Persiapan, 2. Tahap Pelaksanaan, 3. Tahap Analisis Data.

Penelitian ini telah dilaksanakan pada bulan April 2018, di SMA Negeri 06 Kota Bengkulu. Populasi dalam penelitian ini adalah seluruh siswa kelas XI MIPA SMA Negeri 06 Kota Bengkulu tahun ajaran 2017/2018 yang terdiri dari 4 kelas. Pada penelitian ini dilakukan random sampling (pengambilan sampel secara acak). Sampel yang dilibatkan adalah dua kelas yaitu kelompok eksperimen dan kelompok kontrol. Kelompok eksperimen kelas XI MIPA D berjumlah 36 orang dan kelompok kontrol kelas XI MIPA C berjumlah 36 orang.

Teknik yang digunakan dalam pengumpulan data pada penelitian ini adalah tes dan dokumentasi. Data yang dikumpulkan dalam tes adalah data tentang hasil belajar berupa kemampuan kognitif dan kemampuan berpikir kritis yang diperoleh melalui pretes dan postes. Dokumentasi digunakan untuk mengetahui proses pembelajaran yang berlangsung di kelas eksperimen maupun di kelas kontrol, misalnya dokumentasi foto dan arsip-arsip. Pendistribusian alat pada sampel dan waktu pelaksanaan pengambilan data penelitian dilakukan sesuai dengan jadwal pelajaran biologi di SMA Negeri 06 Kota 
Bengkulu. Dengan demikian instrumen yang digunakan dalam penelitian ini yaitu lembar tes berpikir kritis dan tes hasil belajar. Tes yang digunakan untuk menjaring data berpikir kritis merupakan tes yang diadopsi dari instrumen Berpikir Kritis Ennis dalam bentuk essai yang berjumlah lima soal. Selanjutnya tes yang digunakan untuk menjaring hasil belajar siswa yaitu tes dengan format pilihan ganda yang berjumlah 10 soal. Analisis terhadap data penelitian dilakukan bertujuan untuk menguji kebenaran hipotesis yang diajukan dalam penelitian. Data dianalsiis melalui analisis uji-t dengan bantuan software SPSS. Dimana data akan dilakukan uji prasyarat yaitu uji normalitas dan uji homogenitas sebelum dilakukan analisis uji-t.

\section{HASIL PENELITIAN DAN PEMBAHASAN}

Pengambilan data kemampuan berpikir kritis siswa menggunakan tes soal esai sebanyak 5 butir soal. Tes ini diberikan pada saat sebelum proses pembelajaran dilaksanakan. Data kemampuan berpikir kritis siswa ini didapat dari 72 siswa, dimana terdiri dari 36 orang siswa kelas eksperimen (XI MIPA D) dan 36 orang siswa kelas kontrol (XI MIPA C). Data tersebut dapat dilihat pada Tabel 1 di bawah ini.

Tabel 1. Rata-Rata Pretes Kemampuan Berpikir Kritis

\begin{tabular}{lccc} 
& Perhitungan & Kelas & Kontrol \\
\hline Jumlah Skor & 1325 & 1435 \\
Skor Tertinggi & 50 & 55 \\
Skor Terendah & 25 & 30 \\
Rata-rata & 36,80 & 39,86 \\
\hline
\end{tabular}

Berdasarkan Tabel 1 terlihat bahwa rata-rata kemampuan awal berpikir kritis siswa pada kelas PBL (XI MIPA D) adalah 36,80 dengan skor tertinggi yang diperoleh yaitu 50 dan skor terendah 25. Sedangkan rata-rata kemampuan awal berpikir kritis pada kelas kontrol (XI MIPA C) adalah 39,86 dengan skor tertinggi yaitu 55 dan skor terendah 30 . Selanjutnya uji normalitas dengan menggunakan program SPSS 20.0 dilakukan untuk mengetahui apakah data tersebut berdistribusi normal atau tidak.

Uji normalitas pretes kemampuan berpikir kritis siswa dikatakan berdistribusi normal apabila Asymp. sig. (2 tailed) $>a=0,05$. Data pretes kemampuan berpikir kritis siswa yang diperoleh dengan pembelajaran problem based learning (pbl) menggunakan media audio visual dengan nilai signifikansi sebesar 0,697 yang artinya lebih besar dari $0,05(0,697>0,05)$. Sehingga dapat disimpulkan bahwa data pretes kemampuan berpikir kritis siswa berdistribusi normal. Setelah uji normalitas data diketahui dilanjutkan dengan uji homogenitas varians dengan menggunakan uji Levene Stastistic. Uji homogenitas ini berfungsi untuk mengetahui apakah data pretes kemampuan berpikir kritis dari kelas eksperimen dan kelas kontrol homogen atau tidak. Suatu data dikatakan homogen jika nilai Levene Statistic maupun signifikansinya lebih besar dari 0,05 (sig >0,05). Hasil uji homogenitas varians data pretes kemampuan berpikir kritis siswa diperoleh sebesar 0,845 yang artinya lebih besar dari 0,05 $(0,845>0,05)$. Sehingga dapat disimpulkan bahwa data pretes kemampuan berpikir kritis siswa pada kelas eksperimen dan kelas kontrol mempunyai varians yang homogen.

Setelah diketahui data pretes kemampuan berpikir kritis siswa berdistribusi normal dan mempunyai varians yang homogen, maka untuk melihat perbedaan pretes antara kelas eksperimen (XI MIPA D) dan kelas kontrol (XI MIPA C) selanjutnya akan dilanjutkan dengan uji-t, dapat dilihat pada Tabel 2. 
Tabel 2. Hasil Uji-t Pretest Kemampuan Berpikir Kritis

\begin{tabular}{lccc}
\hline \multirow{2}{*}{ T-test for Equality of Means } & \multicolumn{2}{c}{ Kemampuan Berpikir Kritis Siswa } \\
& Equal Variances Assumed & Equal Variances Non Assumed \\
\hline T & $-1,629$ & $-1,629$ \\
Df & 70 & 67,701 \\
Sig. (2-tailed) &, 108 &, 108 \\
\hline
\end{tabular}

Berdasarkan Tabel 2 di atas dapat dilihat bahwa hasil uji-t diperoleh $p$ value dari uji-t sebesar 0,108 lebih besar dari $0,05(0,108>0,05)$. Maka dapat disimpulkan bahwa tidak ada perbedaan yang signifikan dari skor pretes kemampuan berpikir kritis siswa untuk kedua sampel yaitu kelas eksperimen dan kelas kontrol.

Selanjutnya postes diberikan untuk mengetahui sejauh mana pemahaman siswa terhadap pembelajaran yang telah diberikan baik pada kelas eksperimen mapun kelas kontrol, serta untuk mengetahui apakah model pembelajaran problem based learning (pbl) yang telah diberikan memiliki perbedaan atau tidak terhadap kemampuan berpikir kritis siswa di kelas konvensional dan eksperimen. Analisis data postes kemampuan berpikir kritis dapat dilihat pada Tabel 3 di bawah.

Tabel 3. Rata-Rata Postes Kemampuan Berpikir Kritis

\begin{tabular}{|c|c|c|}
\hline \multirow{2}{*}{ Perhitungan } & \multicolumn{2}{|c|}{ Kelas } \\
\hline & Eksperimen & Kontrol \\
\hline Jumlah Skor & 2855 & 2515 \\
\hline Skor Tertinggi & 85 & 80 \\
\hline Skor Terendah & 70 & 55 \\
\hline Rata-rata & 79,30 & 69,86 \\
\hline
\end{tabular}

Berdasarkan Tabel 3 dapat diketahui bahwa rata-rata kemampuan berpikir kritis siswa pada kelas eksperimen adalah 79,30 dengan skor tertinggi 85 dan skor terendah 70 . Selanjutnya kelas kontrol mendapatkan rata-rata 69,86 dengan skor tertinggi 80 dan skor terendah 55 . Selanjutnya uji normalitas dengan menggunakan program SPSS 20.0 dilakukan untuk mengetahui apakah data tersebut berdistribusi normal atau tidak.

Uji normalitas postes kemampuan berpikir kritis siswa dikatakan berdistribusi normal apabila Asymp. sig. (2 tailed) $>a=0,05$. Data postes kemampuan berpikir kritis siswa dengan pembelajaran problem based learning (pbl) menggunakan media audio visual dengan nilai signifikansi sebesar 0,313 lebih besar dari $0,05(0,313>0,05)$ yang artinya data posttest kemampuan berpikir kritis siswa berdistribusi normal. Setelah uji normalitas data diketahui dilanjutkan dengan uji homogenitas varians dengan menggunakan uji Levene Stastistic. Uji homogenitas ini berfungsi untuk mengetahui apakah data postes kemampuan berpikir kritis dari kelas eksperimen dan kelas kontrol homogen atau tidak. Suatu data dikatakan homogen jika nilai Levene Statistic maupun signifikansinya lebih besar dari 0,05 (sig > 0,05). Hasil uji homogenitas varians data postes yaitu dengan signifikansi sebesar 0,287 yang artinya lebih besar dari $0,05(0,287>0,05)$. Sehingga dapat disimpulkan bahwa data postes kemampuan berpikir kritis siswa pada kelas eksperimen dan kelas kontrol mempunyai varians yang homogen.

Setelah diketahui data postes kemampuan berpikir kritis siswa berdistribusi normal dan mempunyai varians yang homogen, maka untuk melihat pengaruh postes antara kelas eksperimen (XI MIPA D) dan kelas kontrol (XI MIPA C) selanjutnya akan dilanjutkan dengan uji-t, dapat dilihat pada Tabel 4. 
Tabel 4. Hasil Uji-t Posttest Kemampuan Berpikir Kritis

\begin{tabular}{lrr}
\hline \multirow{2}{*}{ T-Test For Equality Of Means } & \multicolumn{2}{c}{ Kemampuan Berpikir Kritis Siswa } \\
& Equal Variances Assumed & Equal Variances Non Assumed \\
\hline T & 6,414 & 6,414 \\
Df & 70 & 65,493 \\
Sig. (2-tailed) &, 000 &, 000 \\
\hline
\end{tabular}

Berdasarkan Tabel 4 diketahui bahwa hasil uji-t diperoleh $p$ value dari uji-t sebesar 0,000 lebih kecil dari $0,05(0,000<0,05)$ serta $T_{\text {hitung }} 6,414$ dan $T_{\text {tabel }} 1,994$ artinya $T_{\text {hitung }}$ lebih besar dari $T_{\text {tabel }}(6,414$ $>1,994)$. Maka dapat disimpulkan terdapat perbedaan yang signifikansi dari skor postes kemampuan berpikir kritis pada kelas eksperimen dengan menggunakan model pembelajaran pbl menggunakan media audio visual dan kelas kontrol menggunakan pembelajaran konvensional. Pengambilan data hasil belajar siswa menggunakan tes soal objektif sebanyak 10 butir soal. Tes ini diberikan pada saat sebelum proses pembelajaran dilaksanakan. Data hasil belajar kognitif ini didapat dari 72 siswa. Data pretes hasil belajar kognitif dapat dilihat pada Tabel 5 .

Tabel 5. Rata-Rata Pretes Hasil Belajar Kognitif

\begin{tabular}{lcc}
\multicolumn{1}{c}{ Perhitungan } & Eksperimen & Kelas \\
\hline Jumlah Skor & 1250 & Kontrol \\
Skor Tertinggi & 50 & 1310 \\
Skor Terendah & 20 & 60 \\
Rata-rata & 34,72 & 20 \\
\hline
\end{tabular}

Berdasarkan Tabel 5 dapat diketahui bahwa rata-rata hasil belajar kognitif awal siswa pada kelas eksperimen (XI MIPA D) adalah 34,72 dengan skor tertinggi yang diperoleh yaitu 50 dan skor terendah 20. Sedangkan rata-rata kemampuan awal hasil belajar kognitif siswa pada kelas kontrol (XI MIPA C) adalah 36,38 dengan skor tertinggi yaitu 60 dan skor terendah 20. Selanjutnya uji normalitas dengan menggunakan program SPSS 20.0 dilakukan untuk mengetahui apakah data tersebut berdistribusi normal atau tidak.

Uji normalitas pretes hasil belajar kognitif siswa dikatakan berdistribusi normal apabila Asymp. sig. (2 tailed $)>a=0,05$. Data pretest hasil belajar kognitif siswa yang diperoleh dengan pembelajaran problem based learning (pbl) menggunakan media audio visual dengan nilai signifikansi sebesar 0,133 yang artinya lebih besar dari $0,05(0,133>0,05)$. Sehingga dapat disimpulkan bahwa data pretes hasil belajar kognitif siswa berdistribusi normal. Selanjutnya akan dilakukan uji homogenitas varians dengan menggunakan uji Levene Statistic. Adapun hasil uji homogenitas varians data pretes siswa adalah sebesar 0,921 yang artinya lebih besar dari $0,05(0,921>0,05)$. Sehingga dapat disimpulkan bahwa pretes hasil belajar kognitif kedua sampel mempunyai varians homogen yang sama.

Setelah diketahui bahwa data pretest hasil belajar kognitif siswa berdistribusi normal dan mempunyai varians yang homogen, maka untuk melihat pengaruh pretest antara kelas eksperimen (XI MIPA D) dan kelas kontrol (XI MIPA C) dilanjutkan dengan uji-t, dapat dilihat pada Tabel 6.

Tabel 6. Hasil Uji-t Pretest Hasil Belajar Kognitif

\begin{tabular}{lcc}
\hline \multirow{2}{*}{ T-Test For Equality Of Means } & \multicolumn{2}{c}{ Hasil Belajar Kognitif Siswa } \\
& Equal Variances Assumed & Equal Variances Non Assumed \\
\hline T &,- 641 &,- 641 \\
Df & 70 & 63,479 \\
Sig. (2-tailed) &, 524 &, 524 \\
\hline
\end{tabular}

Meti Herlina, dkk - Perbedaan kemampuan berpikir kritis dan hasil belajar kognitif ... 
Berdasarkan Tabel 6 dapat dilihat dari hasil uji-t diperoleh p-value dari uji-t sebesar 0,524 lebih besar dari 0,05 $(0,524>0,05)$. Maka kesimpulannya yaitu tidak ada perbedaan yang signifikan dari skor pretes kemampuan awal siswa untuk kedua sampel yaitu kelas eksperimen (XI MIPA D) dan kelas kontrol (XI MIPA C). Data postes kemampuan hasil belajar kognitif siswa dengan sampel 72 orang siswa, dimana kelas eksperimen dan kelas kontrol masing-masing terdiri 36 orang siswa. Analisis data postes hasil belajar kognitif siswa dapat dilihat pada Tabel 7 dibawah ini.

Tabel 7. Rata-Rata Posttest Hasil Belajar Kognitif

\begin{tabular}{lcc}
\multicolumn{1}{c}{ Perhitungan } & Kelas & Kontrol \\
\hline Jumlah skor & 2870 & 2410 \\
Skor tertinggi & 90 & 80 \\
Skor terendah & 60 & 50 \\
Rata-rata & 79,72 & 66,94 \\
\hline
\end{tabular}

Berdasarkan Tabel 7 diketahui bahwa terdapat peningkatan baik pada kelas eksperimen maupun kelas kontrol, yang mana dilihat dari rata-rata untuk kelas eksperimen yang awalnya sebesar 34,72 meningkat menjadi 79,72 sedangkan nilai rata-rata untuk kelas kontrol dari 36,38 meningkat menjadi 66,94 . Selanjutnya uji normalitas dengan menggunakan software SPSS dilakukan untuk mengetahui apakah data tersebut berdistribusi normal atau tidak. Uji normalitas postes hasil belajar kognitif siswa dikatakan berdistribusi normal apabila Asymp. sig. $(2$ tailed) $>a=0,05$. Data postes hasil belajar kognitif siswa yang diperoleh dengan pembelajaran problem based learning (pbl) menggunakan media audio visual dengan nilai signifikansi sebesar 0,117 yang artinya lebih besar dari 0,05 $(0,117>0,05)$. Sehingga dapat disimpulkan bahwa data postes hasil belajar kognitif siswa berdistribusi normal.

Uji homogenitas untuk mengetahui apakah kedua sampel tersebut mempunyai varians homogen yang sama atau tidak menggunakan uji Levene Statistic. Adapun data yang diperoleh adalah sebesar 0,551 dimana lebih besar dari $0,05(0,551>0,05)$. Maka dapat disimpulkan bahwa kedua sampel tersebut mempunyai varians yang sama. Setelah uji normalitas dan uji homogenitas kedua sampel tersebut diketahui, maka selanjutnya akan dilakukan uji-t untuk melihat perbedaan postes antara kelas eksperimen (XI MIPA D) dan kelas kontrol (XI MIPA C), dapat dilihat pada Tabel 8 di bawah.

Tabel 8. Hasil Uji-t Posttest Hasil Belajar Kognitif

\begin{tabular}{lcc}
\hline \multirow{2}{*}{ T-Test For Equality Of Means } & \multicolumn{2}{c}{ Hasil Belajar Kognitif Siswa } \\
& Equal Variances Assumed & Equal Variances Non Assumed \\
\hline T & 5,826 & 5,826 \\
Df & 70 & 66,128 \\
Sig. (2-tailed) &, 000 &, 000 \\
\hline
\end{tabular}

Berdasarkan Tabel 8 hasil uji-t diperoleh nilai p-value statistic sebesar 0,000 lebih kecil dari 0,05 $(0,000<0,05)$ serta $T_{\text {hitung }} 5,826$ dan $T_{\text {tabel }} 1,994$ artinya $T_{\text {hitung }}$ lebih besar dari $T_{\text {tabel }}(5,826>1,994)$. Maka kesimpulannya adalah terdapat perbedaan yang signifikan dari skor posttest hasil belajar kognitif siswa pada kedua sampel yaitu kelas eksperimen menggunakan model pembelajaran pbl menggunakan media audio visual dan kelas kontrol menggunakan pembelajaran konvensional.

Pembelajaran dengan model problem based learning (pbl) menggunakan media audio visual dapat meningkatkan kemampuan berpikir kritis siswa karena di pengaruhi oleh langkah-langkah dalam proses pembelajarannya yang lebih melibatkan siswa, dimana langkah-langkahnya dimulai dengan guru memberikan sebuah permasalahan kepada siswa dengan menggunakan bantuan media audio visual,

49 Meti Herlina, dkk - Perbedaan kemampuan berpikir kritis dan hasil belajar kognitif ... 
untuk memecahkan permasalahan tersebut guru membagi siswa menjadi ke dalam beberapa kelompok dan kemudian guru memberikan lembar diskusi siswa yang berisi tentang permasalahan kepada setiap kelompok. Kemudian siswa disuruh menganalisis dan mencari solusi dari masalah tersebut, setelah berdiskusi guru meminta 1 orang perwakilan dari kelompok untuk menyampaikan pendapatnya tentang masalah yang telah diberikan oleh guru, sehingga dengan langkah-langkah tersebut bisa menjadikan siswa lebih aktif dalam berpikir. Hal ini didukung oleh pendapat Dianawati dkk (2017) mengungkapkan bahwa pembelajaran berbasis masalah merupakan pembelajaran yang diawali dengan adanya adanya suatu permasalahan, kemudian siswa menggunakan pengetahuan yang dimilikinya untuk memecahkan masalah tersebut. Pemberian suatu masalah dalam kelompok siswa pada setiap kegiatan pembelajaran dapat memberikan pengalaman belajar yang beragam pada siswa seperti kerjasama dan interaksi dalam kelompok, sehingga mereka terdorong berperan aktif dalam berpikir. Hal ini diperkuat oleh pendapat Happy \& Widjajanti (2014) menyatakan bahwa model pembelajaran problem based learning (pbl) diawali dengan memberikan beberapa masalah yang memang menuntut siswa menggunakan beberapa cara atau menyediakan beberapa solusi dalam rangka memecahkan masalah. Dalam memecahkan masalah siswa dituntut untuk bekerja sama dalam kelompok, sehingga membuat siswa menjadi lebih aktif berpikir.

Peningkatan kemampuan berpikir kritis siswa juga dipengaruhi oleh media audio visual. Media audio visual disini sebagai alat bantu siswa dalam menganalisis masalah, dimana dengan adanya bantuan dari media audio visual akan membuat siswa lebih mudah dalam memecahkan suatu masalah. Berdasarkan hasil pengamatan yang dilakukan oleh peneliti pada saat proses pembelajaran berlangsung di kelas eksperimen dengan menggunakan media audio visual, dapat menstimulus siswa terhadap permasalahan sesuai tujuan pembelajaran. Penyajian materi dengan disertai audio visual dapat meningkatkan perhatian, semangat, motivasi, dan daya ingat siswa dalam proses pembelajaran, dan media audio visual juga bisa memunculkan penjelasan materi yang bisa dilihat maupun didengar oleh siswa, sehingga akan meningkatkan pemahaman konsep dan kemampuan berpikir tingkat tinggi siswa. Hal ini diperkuat oleh pendapat Nafiah dan Suyanto (2014) menyatakan bahwa model pbl didasarkan pada situasi permasalahan dan membingungkan sehingga akan membangkitkan rasa ingin tahu siswa sehingga siswa tertarik untuk menyelidiki permasalahan tersebut. Pada saat siswa melakukan penyelidikan, maka siswa akan berpikir untuk menyelidiki masalah, menganalisa berdasarkan bukti dan mengambil keputusan berdasarkan hasil penyelidikan sehingga membuat kemampuan berpikir kritis siswa meningkat.

Selain itu, dalam memecahkan masalah yang terdapat di lembar diskusi siswa secara berkelompok akan membuat siswa terampil dan terlatih berpikir untuk memecahkan suatu masalah dan mencari bagaimana cara dalam menyelesaikan masalah tersebut, sehingga siswa memperoleh solusi dan kesimpulan. Hal tersebut didukung oleh hasil penelitian yang dilakukan oleh Prihmardoyo (2013) menyatakan bahwa media audio visual memiliki banyak kelebihan untuk meningkatkan keterampilan berpikir kritis diantaranya mengembangkan pikiran dan pendapat para siswa, mengembangkan imajinasi peserta didik, mengembangkan keterampilan dan rangsangan terhadap materi serta menjadikan siswa berusaha berpikir lebih keras dalam berdiskusi.

Menggunakan model problem based learning (pembelajaran berbasis masalah) dapat memotivasi siswa untuk lebih aktif dan kritis dalam berpikir dan memahami materi. Siswa dapat melakukan investigasi terhadap permasalahan yang nyata di sekitarnya, sehingga mereka mendapatkan kesan yang mendalam dan lebih bermakna tentang apa yang mereka pelajari. Dengan kata lain model problem based learning dapat memotivasi siswa untuk terlibat aktif dalam memecahkan 
masalah (Winarti, 2015). Hal ini diperkuat oleh pendapat Nafiah dan Suyanto (2014) menyatakan bahwa model PBL dimulai dari adanya suatu permasalahan, sehingga dapat memicu munculnya rasa ingin tahu siswa. Dengan demikian hal ini dapat menyebabkan siswa lebih tertarik untuk menyelidiki permasalahan tersebut. Pada saat siswa melakukan penyelidikan, maka siswa secara langsung akan tertarik untuk menyelidiki, memecahkan masalah, menganalisis berdasarkan bukti dan mengambil keputusan berdasarkan hasil penyelidikan, sehingga membuat kemampuan berpikir kritis siswa dapat meningkat. Pembelajaran dengan model problem based learning (pbl) menggunakan media audio visual dapat meningkatkan hasil belajar kognitif siswa, bisa terjadi karena pada kelas eksperimen menggunakan model pembelajaran problem based learning ( $\mathrm{pbl}$ ) Berbantuan media audio visual sehingga siswa pada kelas eksperimen dapat bekerja sama dengan kelompok dan mampu memecahkan permasalahan yang diberikan oleh guru.

Dalam proses pembelajaran ini tidak mengharapkan siswa hanya sekadar mendengarkan penjelasan dari guru, mencatat kemudian menghafal materi pelajaran yang diajarkan, akan tetapi melalui strategi pembelajaran berbasis masalah akan membuat siswa aktif berpikir, ditambah lagi dengan adanya penggunaan media audio visual akan membuat siswa lebih mudah dalam mencari solusi dan akhirnya menyimpulkannya, sehingga terciptanya interaksi antara guru dengan siswa, siswa dengan siswa yang lainya yang membuat siswa menjadi lebih aktif pada saat proses pembelajaran berlangsung. Hal ini didukung oleh pendapat Susilo (2012) menyatakan bahwa pembelajaran berbasis masalah (pbl) adalah strategi pembelajaran yang menarik, dari pada membaca atau mendengarkan tentang fakta-fakta dan konsep dari guru, siswa memecahkan masalah realistis yang membuat siswa aktif dalam berpikir dan PBL juga mendukung pengembangan strategi belajar mandiri yang memudahkan siswa untuk mempertahankan dan menerapkan pengetahuan serta strategi untuk memberikan solusi.

Hal itu diperkuat oleh pendapat Cahyo dkk (2017) menyatakan bahwa problem based learning (pbl) merupakan suatu model pembelajaran yang dapat mengarahkan siswa menjadi pribadi yang lebih mandiri dan terlibat langsung secara aktif dalam pemecahan masalah. Pbl dapat memungkinkan siswa keterampilan berpikir kritis siswa dapat berkembang dengan baik, sehingga mereka mampu mencari solusi untuk memecahkan masalah yang dighadapi. Tidak hanya membantu siswa memahami konsep konsep yang sulit, model pbl juga dapat menumbuhkan keterampilan dalam bekerjasama dalam kelompoknya serta melatih siswa dalam berpikir mencari solusi dalam memecahkan masalah. Hal ini tentunya dapat meningkatkan keterampilan berpikir kritis siswa (Dewi dkk, 2017).

Selain itu penggunaan media audio visual dalam proses pembelajaran juga berpengaruh terhadap hasil belajar kognitif siswa, karena dengan adanya penggunaan media audio visual dapat menampilkan bagian organ pada materi sistem saraf yang tidak dapat dilihat secara langsung oleh siswa serta membantu dalam proses pemecahan masalah dan akan membuat siswa lebih tertarik dan bersemangat untuk belajar. Dengan meningkatnya kemampuan menghafal siswa secara tidak langsung akan mempengaruhi hasil belajar mereka. Hal ini sejalan dengan hasil penelitian yang dilakukan Paramartha dkk (2016) menyatakan bahwa media audio visual memiliki beberapa keunggulan, yaitu merangsang partisipasi siswa aktif, dapat menunjukkan pengalaman dunia luar ke dalam kelas, siaran yang aktual dapat memberikan kemudahan pada siswa untuk dapat memahami suatu konsep dengan utuh. Hal ini diperkuat oleh pendapat Supriadi dkk (2012) menyatakan bahwa melalui media pembelajaran audio visual dengan menampilkan tayangan-tayangan konkret berupa film pendek tentang materi yang dibelajarkan membuat siswa menjadi lebih tertarik untuk mengikuti pembelajaran. 
Model pembelajaran problem based learning (pbl) dengan menggunakan media audio visual merupakan model pembelajaran inovatif yang mengupayakan siswa untuk dapat menyelesaikan masalah, sehingga hasil belajar kognitif siswa menjadi lebih optimal. Alfian dkk (2015) menyatakan bahwa problem based learning ( $\mathrm{pbl}$ ) merupakan model pembelajaran yang mendorong siswa untuk mengenal cara belajar untuk mencari penyelesaian masalah-masalah di dunia nyata. Dalam proses pembelajarannya siswa dilatih untuk memecahkan masalah, sehingga hasil belajar siswa bisa optimal. Hal ini didukung oleh pendapat Santi dkk (2014) menyatakan bahwa penggunaan pembelajaran berbasis masalah berbantuan media audio visual dapat meningkatkan hasil belajar siswa. Hal ini disebabkan karena media ini memungkinkan penyampaian materi yang bersifat abstrak dapat dilihat dan didengar seolah direfrentasikan nyata, sehingga mudah untuk dipahami.

\section{SIMPULAN}

Berdasarkan hasil penelitian beberapa hal yang dapat disimpulkan yaitu terdapat perbedaan kemampuan berpikir kritis siswa yang diajar dengan model pbl dengan menggunakan media audio visual. Selain itu hasil juga menunjukkan bahwa terdapat perbedaan kemampuan berpikir kritis siswa yang diajar dengan model pbl dengan menggunakan media audio visual. Hal ini dikuatkan dari nilai nilai t-hitung keterampilan berpikir kritis sebesar 6,414 (> t-tabel) dan hasil belajar kognitif sebesar 5,826 (> ttabel).

\section{UCAPAN TERIMA KASIH}

Ucapan terima kasih kepada siswa SMA Negeri 06 Kota Bengkulu dan semua pihak yang terlibat dalam pelaksanaan penelitian.

\section{RUJUKAN}

Alfian, F.I., Linuwih, S., \& Sugiyanto. (2015). Efektivitas Pembelajaran Model PBL Menggunakan Audio Visual Untuk Meningkatkan Hasil Belajar Siswa Mapel IPA Kelas VII. Unnes Physics Education Journal, 4, 49-56. Retrieved from https://journal.unnes.ac.id/sju/index.php/upej/article/view/7423

Cahyo, N.R., Wasitohadi., \& Rahayu, S.T. (2017). Upaya Meningkatkan Hasil Belajar IPS Melalui Model Problem Based Learning (PBL) Berbantuan Media Audio Visual Pada Siswa Kelas 4 SD. Jurnal Basicedu, 2 (1), 28-31. Retrieved from https://media.neliti.com/media/publications/278067-upayameningkatkan-hasil-belajar-ips-mel-a94fb24b.pdf

Dewi, F.R.A., Putra, A.K., \& Asri, S.A. (2017). Pengaruh Model Pembelajaran Problem Based Learning Berbantuan Media Audio Visual Terhadap Hasil Belajar IPS Siswa Kelas IV. E-Journal PGSD Universitas Pendidikan Ganesha, 5, 2, 1-10. Retrieved from https://ejournal.undiksha.ac.id/ index.php/JJPGSD/article/view/10657

Dianawati, L.N. Riastini, N. \& Pudjawan. (2017). Pengaruh Model Pembelajaran Problem Based Learning Terhadap Keterampilan Berpikir Kritis IPA Siswa Kelas V SD No. Ungasan Kecamatan Kuta Selatan. E-Journal PGSD Universitas Pendidikan Ganesha 5 (2), 1-7. Retrieved from https://ejournal.undiksha.ac.id/index.php/JJPGSD/article/view/10985

Fradisa, L \& Kartika, K. (2019) Penerapan Modul Biologi Berorientasi Problem Based Learning Untuk Meningkatkan Hasil Belajar Kognitif Mahasiswa Keperawatan. Edubiotik: Jurnal Pendidikan, Biologi dan Terapan, 4(2), 121-127. https://doi.org/10.33503/ebio.v4i02.512

Happy, N. \& Widjajanti, B.D. (2014). Keefektifan PBL Ditinjau Dari Kemampuan Berpikir Kritis Dan Kreatif Matematis, Serta Self-Esteem Siswa SMP. Jurnal Riset Pendidikan Matematika, 1, 1, 4857. Retrieved from https://journal.uny.ac.id/index.php/jrpm/article/view/2663

Hartati, R., \& Sholihin. (2015). Meningkatkan Kemampuan Berpikir Kritis Siswa Melalui Implementasi Model Problem Based Learning (PBL) Pada Pembelajaran IPA Terpadu Siswa SMP. Journal 
Prosiding Simposium Nasional Inovasi dan Pembelajaran Sains, 505-508. Retrieved from http://portal.fmipa.itb.ac.id/snips2015/pages/abstracts1.php

Hasan, R., \& Syatriadni, B. (2018). Pengaruh Model Pembelajaran Berbasis Masalah (Pbm) Terhadap Kemampuan Berpikir Kritis Dan Hasil Belajar Biologi Siswa SMA Negeri 06 Kota Bengkulu. Prosiding Seminar Nasional Simbiosis lii, Madiun, 15 September 2018. Retrieved from http://prosiding.unipma.ac.id/index.php/simbiosis/article/view/651

Hasmiati, Jumadi, O., \& Rachmawaty. (2018). Penerapan Model Problem Based Learning (PBL) Dalam Meningkatkan Kemampuan Berpikir Kreatif dan Hasil Belajar Siswa. Prosiding Seminar Nasional Biologi dan Pembelajarannya. Retrieved from http://eprints.unm.ac.id/14391/

Jamilatus, T., S., Usudo, B., \& Riyadi. (2018). Higher Order Thingking (Hot) Problems to Develop Critical Thinking Ability And Student Self Efficacy In Learning Mathematics Primary Schools. 1 st National Seminar on Elementary Education (SNPD 2018), SHEs: Conference Series 1 (1) $917-$ 925. Retrieved from https://jurnal.uns.ac.id/SHES/article/view/23676

Kinaseh., Subekti, N., \& Pribadi, T.A. (2015). Pengaruh Model Problem Based Learning Dengan Media Animasi Flash Terhadap Hasil Belajar Dan Aktivitas Siswa. Unnes Journal Of Biology Education, 4 (3), 317-321. Retrieved from https://journal.unnes.ac.id/sju/index.php/ujbe/article/view/9587

Kirmizi F, Saygi C and Yurdakal I 2015 Determine the Relationship Between the Disposition Of Critical Thinking And The Perception About Problem Solving Skills. Procedia - Social and Behavioral Sciences, 191, 657-661. https://doi.org/10.1016/j.sbspro.2015.04.719

Nafiah, Y., N. (2014). Penerapan Model Problem-Based Learning Untuk Meningkatkan Keterampilan Berpikir Kritis Dan Hasil Belajar Siswa. Jurnal Pendidikan Vokasi. Retrieved from https://journal.uny.ac.id/index.php/jpv/article/view/2540

Nasution, U., S., Z., \& Sirait, M. Pengaruh Model Problem Based Learning Dan Kemampuan Berpikir Kritis Terhadap Kemampuan Pemecahan Masalah. Jurnal Pendidikan Fisika, 5(2), 112-117. Retrieved from https://media.neliti.com/media/publications/120080-ID-none.pdf

Novitasari, R., Anggraito, Y.U., \& Ngabekti, S. (2015). Efektivitas Model Problem Based Learning Berbantuan Media Audio Visual Terhadap Motivasi Dan Hasil Belajar Siswa Pada Materi Sistem Ekskresi. Unnes Journal of Biology Education, 4 (3), 298-303. Retrieved from https://journal. unnes.ac.id/sju/index.php/ujbe/article/view/9583

Paramartha, I.M.D., Suniasih, N.W., \& Negara, G.A.O. (2016). Pengaruh Model PBL Berbantuan Media Audio Visual Terhadap Penguasaan Kompetensi Pengetahuan IPA. E-journal PGSD Universitas Pendidikan Ganesha, 4 (1), 1-10. Retrieved from https://ejournal.undiksha.ac.id/index.php/JJPG SD/article/view/7137

Prastowo, A. (2019). Sumber Belajar \& Pusat Sumber Belajar. Depok; Prenadamedia Group.

Pratiwi, Y.P. (2012). Pengaruh Model Pembelajaran Problem Based Learning Terhadap Kemampuan Berpikir Kritis Dan Berpikir Kreatif Siswa Pada Pembelajaran Biologi. Skripsi FKIP USM. Surakarta. Retrieved from https://biologi.fkip.uns.ac.id/wp-content/uploads/2012/02/YENNY-PPK4308128.pdf

Prihmardoyo, W. (2013). Pengaruh Model Pembelajaran Problem Based Learning (PBL) Berbasis Audio Visual Pada Kompetensi Dasar Fungi Terhadap Hasil Belajar Biologi Ditinjau Dari Kemampuan Berpikir Kritis. Jurnal Universitas Sebelas Maret, 4 (1). Retrieved from https://jurnal.fkip.uns.ac.id/index.php/kimia/article/view/4617

Reta, I.K. (2012). Pengaruh Model Pembelajaran Berbasis Masalah Terhadap Keterampilan Berpikir Kritis Ditinjau dari Gaya Kognitif Siswa. Jurnal Pendidikan Dan Pembelajaran IPA Indonesia. 2(1). Retrieved from http://oldpasca.undiksha.ac.id/e-journal/index.php/jurnal_ipa/article/view/403

Santi, P., Suadnyana., \& Wiyasa. (2014). Pengaruh Model Pembelajaran Kooperatif Berbasis Masalah Berbantuan Media Audiovisual Terhadap Hasil Belajar IPA Kelas V SD Negeri 1 Ubud Gianyar. Jurnal Mimbar PGSD Universitas Pendidikan Ganesha, 2 (1). Retrieved from https://ejournal.un diksha.ac.id/index.php/JJPGSD/article/view/2494 
Sari, D.D. (2012). Penerapan Model Problem Based Learning (PBL) Untuk Meningkatkan Kemampuan Berpikir Kritis Peserta Didik Pada Pembelajaran IPA kelas VIII SMP Negeri 5 Sleman. Retrieved from https://eprints.uny.ac.id/9174/

Sucipto. (2017). Pengembangan Ketrampilan Berpikir Tingkat Tinggi Dengan Menggunakan Strategi Metakognitif Model Pembelajaran Problem Based Learning. Jurnal Pendidikan, 2 (1), 63-71.

Retrieved from http://repository.unitomo.ac.id/333/

Suharjanto, A., Sawiji, H., \& Susilowaty. (2013). Penerapan Media Pembelajaran Dengan Penggunaan Software Prezi Dalam Upaya Meningkatkan Minat Belajar Mata Diklat Komunikasi. Jurnal Pendidikan Administrasi Perkantoran. Retrieved from https://jurnal.fkip.uns.ac.id/index.php/pap larticle/view/2544

Supriadi, M.I, Sujana, W.I., \& Wiarta. (2012). Model Pembelajaran Problem Based Learning (PBL) Berbantuan Media Audio Visual Berpengaruh Terhadap Hasil Belajar IPS Siswa Kelas IV SD Gugus Ubud Gianyar. Journal Universitas Pendidikan Ganesha. Retrieved from https://ejournal.undiksha.ac.id/index.php/JJPGSD/article/viewFile/1233/1097

Susilo, A.B. (2012). Pengembangan Model Pembelajaran IPA Berbasis Masalah Untuk Meningkatkan Motivasi Belajar Dan Berpikir Kritis Siswa SMP. Journal of Primary Educational, 1 (1), 57-63. Retrieved from https://journal.unnes.ac.id/sju/index.php/jpe/article/view/58

Syahfitri, J., Firman, H., Redjeki, S \& Sriyati, S. (2018). Validitas dan Reliabilitas Tes Disposisi Berpikir Kritis Dalam Biologi Perguruan Tinggi. Prosiding Seminar Nasional Pendidikan Sains dan Teknologi, Universitas Muhammadiyah Semarang. Retrieved from https://jurnal.unimus.ac.id/ index.php/psn12012010/article/view/4109

Syahfitri, J., Firman, H., Redjeki, S \& Sriyati, S. (2019a). Development and Validation of Critical Thinking Disposition Test in Biology. International Journal of Instruction, 12 (4). https://doi.org/10.29333 /iji.2019.12425a

Syahfitri, J., Firman, H., Redjeki, S \& Sriyati, S. (2019b). Confirmatory Factor Analysis of Critical Thinking Disposition Test in University Biology. Journal of Physics: Conference Series. https://doi.org/10. 1088/1742-6596/1280/3/032001

Syaribuddin., Khaldun, I., \& Musri. (2016). Penerapan Model Pembelajaran Problem Based Learning (Pbl) Dengan Media Audio Visual Pada Materi Ikatan Kimia Terhadap Penguasaan Konsep Dan Berpikir Kritis Peserta Didik SMA Negeri 1 Panga. Jurnal Pendidikan Sains Indonesia. 4 (2), 96 105. Retrieved from http://jurnal.unsyiah.ac.id/JPSI/article/view/7585

Trianto. (2015). Model Pembelajaran Terpadu. Bumi Aksara. Jakarta.

Triyuningsih, E. (2011). Pengaruh Model Pembelajaran Berdasarkan Masalah (Problem Based Learning) Terhadap Kemampuan Berpikir Kritis Siswa. Skripsi Program Studi Pendidikan Biologi FITK UIN. Jakarta.

Winarti. (2015). Implementasi Pendekatan Saintifik Dan Metode Problem Based Learning dan Dampaknya Terhadap Kemampuan Berpikir Kritis Siswa. Jurnal Penelitian dan pendidikan IPA (JPPI), 9 (3),13. Retrieved from http://ejournal.unikama.ac.id/index.php/JPPI/article/download/16 $78 / 1358$

Zubaidah, S. (2016). Keterampilan Abad Ke-21: Keterampilan Yang Diajarkan Melalui Pembelajaran. Prosiding Seminar Nasional Pendidikan Program Studi Pendidikan Biologi STKIP Persada Khatulistiwa Sintang - Kalimantan Barat. Retrieved from https://www.researchgate.net/publication /318013627 